\title{
Sulfur Poisoning of Ni/CGO Anodes: A Long-Term Degradation Study
}

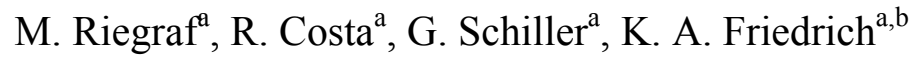 \\ ${ }^{a}$ German Aerospace Centre (DLR), Institute of Engineering Thermodynamics, 70569 \\ Stuttgart, Germany \\ ${ }^{\mathrm{b}}$ Institute for Energy Storage, University of Stuttgart, 70569 Stuttgart, Germany
}

This work presents an in-depth analysis of long-term degradation due to sulfur poisoning of Ni/CGO10-based SOFC. A parameter study of the sulfur-induced long-term degradation of commercial, highperformance single cells was conducted with an accumulated cell testing time of more than one year. The long-term degradation behavior is investigated at $900{ }^{\circ} \mathrm{C}$ for different $\mathrm{H}_{2} \mathrm{~S}$ concentrations and varying $\mathrm{H}_{2} / \mathrm{H}_{2} \mathrm{O} / \mathrm{N}_{2}$ fuel gas atmospheres. The sulfur poisoning periods of the different cells varied from 100 up to $1500 \mathrm{~h}$. The progress of the degradation during the experiments was monitored by means of electrochemical impedance spectroscopy.

It is shown that Ni/CGO anodes can be exposed to 1 ppm $\mathrm{H}_{2} \mathrm{~S}$ and operated without significant irreversible degradation at a current density of $0.5 \mathrm{~A} \cdot \mathrm{cm}^{-2}$ for $1500 \mathrm{~h}$ for certain fuel gas mixtures, demonstrating their promising long-term stability. However, for reduced hydrogen partial pressures in the fuel gas, the same $\mathrm{H}_{2} \mathrm{~S}$ concentration leads to a considerable voltage decrease that is reflected by an increase in anode charge transfer resistance. Furthermore, the microstructural evolution of the $\mathrm{Ni} / \mathrm{CGO}$ is examined ex-situ by means of SEM and correlated to the anode performance degradation. The existence of a stable operating regime for $\mathrm{Ni} / \mathrm{CGO}$ anodes under sulfur exposure is clearly shown and the critical operating parameters are outlined. The presented results give important insights into the degradation processes occurring during long-term operation of $\mathrm{Ni} / \mathrm{CGO}$ anodes as well as strategies for stable SOFC operation. Moreover, the results encourage to further optimize the performance and sulfur tolerance of $\mathrm{Ni} / \mathrm{CGO}$ anodes.

\section{Introduction}

Most prospective SOFC fuels contain undesirable sulfur-containing impurities that lead to the surface poisoning of Ni-based fuel electrodes, which causes a significant SOFC performance penalty (1-6). In this regard, Ni/CGO-based electrodes show a higher sulfur tolerance. Despite their high resistivity and good performance, so far only few studies have studied sulfur poisoning of $\mathrm{Ni} / \mathrm{CGO}$ anodes in detail (7-11). While the performance decrease of SOFC with Ni/YSZ anodes was shown to originate from the poisoning of the Ni surface with sulfur, recent studies of $\mathrm{Ni} / \mathrm{CGO}$ anodes have indicated that the electrochemical charge transfer rather occurs on the CGO surface (double phase boundary) than at the triple phase boundary (TPB) of the Ni/CGO/gas phase. This suggests that the Ni phase might merely act as an electronic conductor (12-14). Since cerium in the CGO based anodes possesses a mixed oxidation state at relevant SOFC operating conditions in reducing atmospheres, that is, it can 
easily change oxidation states between $\mathrm{Ce}^{3+}$ and $\mathrm{Ce}^{4+}$, it provides $\mathrm{CGO}$ its mixed ionic/electronic conductivity and high catalytic activity towards $\mathrm{H}_{2}$ oxidation $(7,9,12,13,15-$ 19).

Multiple research groups have investigated the effect of sulfur-containing fuels on Ni/CGO performance (7-11). However, there are no reports about the long-term degradation of $\mathrm{Ni} / \mathrm{CGO}$ exposed to hydrogen sulfide, although this is essential in determining the feasibility of $\mathrm{Ni} / \mathrm{CGO}$ anode usage in SOFC systems without a desulfurization unit.

This work presents the results of long-term degradation experiments of Ni/CGO-based anodes exposed to different $\mathrm{H}_{2} \mathrm{~S}$-containing $\mathrm{H}_{2} / \mathrm{H}_{2} \mathrm{O} / \mathrm{N}_{2}$ fuel mixtures. The degradation behavior is monitored in-operando by means of electrochemical impedance spectroscopy. Furthermore, SEM measurements are used for post-mortem analysis of the microstructural evolution of the $\mathrm{Ni} / \mathrm{CGO}$ composite anode during the long-term tests.

\section{Experimental Procedure}

Commercial, electrolyte-supported SOFC (ESC) were investigated that employed a $\mathrm{Ni} / \mathrm{CGO} 10\left(\mathrm{Ce}_{0.9} \mathrm{Gd}_{0.1} \mathrm{O}_{1.95}\right)$ anode, a LSM $\left(\left(\mathrm{La}_{0.75} \mathrm{Sr}_{0.25}\right)_{0.95} \mathrm{MnO}_{3}\right) / 3 \mathrm{YSZ}\left(\left(\mathrm{Y}_{2} \mathrm{O}_{3}\right)_{0.03}\left(\mathrm{ZrO}_{2}\right)_{0.97}\right)$ composite cathode and a $3 \mathrm{YSZ}$ electrolyte. The short-term sulfur poisoning behavior of a similar cell was thoroughly characterized in a recent publication (11). The active area of the planar cells was $4 \times 4 \mathrm{~cm}^{2}$ with a total area of $5 \times 5 \mathrm{~cm}^{2}$. The setup for cell testing enables the characterization of up to four cells simultaneously and has been illustrated and described in detail elsewhere $(11,20)$. All gases were supplied via mass flow controllers. $\mathrm{H}_{2}$ was humidified in a water bubbler. $\mathrm{H}_{2} \mathrm{~S}$ was taken from a pressurized bottle containing $150 \mathrm{ppm}$ $\mathrm{H}_{2} \mathrm{~S}$ in $\mathrm{H}_{2}$. In order to avoid sulfur adsorption on the piping and its dissolution in the water bubbler, the sulfur was injected into the fuel stream after humidification right before the cell housing.

The cells were operated with $\mathrm{H}_{2} / \mathrm{H}_{2} \mathrm{O} / \mathrm{N}_{2}$ fuel mixtures and different $\mathrm{H}_{2} \mathrm{~S}$ concentrations at a constant total fuel flow of $1 \mathrm{~L} \cdot \mathrm{min}^{-1}$ for each cell. The cathode was supplied with air at a constant flow of $2 \mathrm{~L} \cdot \mathrm{min}^{-1}$. The cells were heated $\left(3 \mathrm{~K} \cdot \mathrm{min}^{-1}\right)$ up to $950{ }^{\circ} \mathrm{C}$ for sealing and the $\mathrm{NiO}$ was subsequently reduced at $900{ }^{\circ} \mathrm{C}$. The $\mathrm{OCV}$ was checked before starting the tests and confirmed to be higher than $1.22 \mathrm{~V}$ in pure hydrogen for all cells, assuring proper gas tightness of the cells.

For the measurements, two different experiments were conducted with $\mathrm{H}_{2} / \mathrm{N}_{2}$ mixtures of 100:0 and 25:75 and a current density of $0.5 \mathrm{~A} \cdot \mathrm{cm}^{-2}$. For the $\mathrm{H}_{2} / \mathrm{N}_{2}$ 100:0 mixture, two cells were operated over $1500 \mathrm{~h}$. For the $\mathrm{H}_{2} / \mathrm{N}_{2} 25: 75$ mixture two cells were operated over $90 \mathrm{~h}$. One cell was operated at a $\mathrm{H}_{2} \mathrm{~S}$ concentration of $1 \mathrm{ppm}(1500 \mathrm{~h}$ test) or $10 \mathrm{ppm}$ ( $90 \mathrm{~h}$ test) and one as a reference test without sulfur. In order to monitor the degradation process, impedance measurements were carried out once a week (approximately $168 \mathrm{~h}$ ) for the $1500 \mathrm{~h}$ test. For the $90 \mathrm{~h}$ test, measurements were taken after the initial performance drop and right before the start of the regeneration phase. After the desired poisoning time was reached, the hydrogen sulfide supply was switched off, and the gas flow was substituted by pure $\mathrm{H}_{2}$ to regenerate the anodes. Then, the cells were regenerated until the cell voltage stabilized again.

The cells were characterized by electrochemical impedance spectroscopy using an electrochemical workstation (Zahner ${ }^{\circledR}$ PP-240 with Thales software) in a frequency range between $50 \mathrm{mHz}$ and $100 \mathrm{kHz}$ with 8 points/decade. The amplitude of the current stimulus 
was chosen to be $500 \mathrm{~mA}$ and did not trigger a voltage response of higher than $15 \mathrm{mV}$. SEM pictures were recorded with a Zeiss Ultra Plus SEM.

\section{Results and Discussion}

The main objective of the present work is to investigate the influence of sulfur poisoning on the long-term performance of Ni/CGO10 anodes. Figure 1 shows the voltage stability tests over $1500 \mathrm{~h}$ for the two cells at 0 and $1 \mathrm{ppm} \mathrm{H}_{2} \mathrm{~S}$. For the $1 \mathrm{ppm}$ test, the recovered voltage is approximately the same as the initial voltage drop. Interestingly, during the experiment, the irreversible degradation of the sulfur-exposed cell is only slightly larger $(25 \mathrm{mV})$ than the one for the non-sulfur reference test $(14 \mathrm{mV})$.

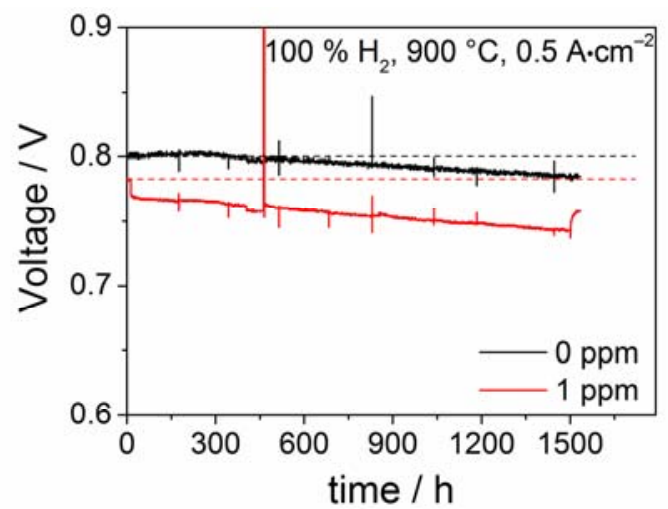

Figure 1. Cell voltage curves as a function of time at $T=900{ }^{\circ} \mathrm{C}$ and $p \mathrm{O}_{2}=0.21 \mathrm{~atm}$. The cells are operated at $i=0.5 \mathrm{~A} \cdot \mathrm{cm}^{-2}, p \mathrm{H}_{2}=1.0 \mathrm{~atm}$, and with $\mathrm{H}_{2} \mathrm{~S}$ concentrations of 0 and $1 \mathrm{ppm}$.

Performance changes during the test were also captured by electrochemical impedance spectra shown in Figure 2. Upon sulfur exposure in the $1 \mathrm{ppm}$ test, the impedance response at frequencies around $0.5 \mathrm{~Hz}$ rapidly increases, which is in agreement with the recently observed poisoning behavior of these anodes (11). The non-sulfur reference test shows mainly an increase in the polarization resistance, specifically the higher frequency arc, which is associated with a cathode process. The resistance of this process also changes for the $1 \mathrm{ppm}$ test. For both tests, the impedance response at low frequencies that corresponds to the anode surface process remains unchanged over the test, indicating that there is no effect on the anode charge transfer process. However, in contrast to the $0 \mathrm{ppm}$ test, the $1 \mathrm{ppm}$ test shows an increase of the ohmic resistance. The increase in polarization resistance of the cell is small, which suggests the absence of major microstructural changes in the anode.

In a recent study of $\mathrm{Ni} / \mathrm{CGO} 40$ anodes, Iwanschitz et al. observed that the main contribution to the overall cell degradation after redox cycling was also an increase in ohmic resistance (18). This was not observed during the same experiments on Ni/YSZ where redox cycling mainly affected the higher frequencies of the impedance spectra and Ni coarsening was witnessed. The authors showed that the electrical conductivity of CGO40 decreases after several redox cycles which could cause an increasing ohmic resistance of Ni/CGO as well, since the CGO transitions from a mixed ionic/electronic conductor (MIEC) to a pure ionic conductor. Recently it could be shown that sulfur diffuses into the CGO bulk phase under polarization $(21,22)$. These studies demonstrate considerable physicochemical interactions between sulfur and $\mathrm{CGO}$, which indicates that high quantities of $\mathrm{H}_{2} \mathrm{~S}$ might cause a drop in the electronic conductivity as observed for redox cycling. 

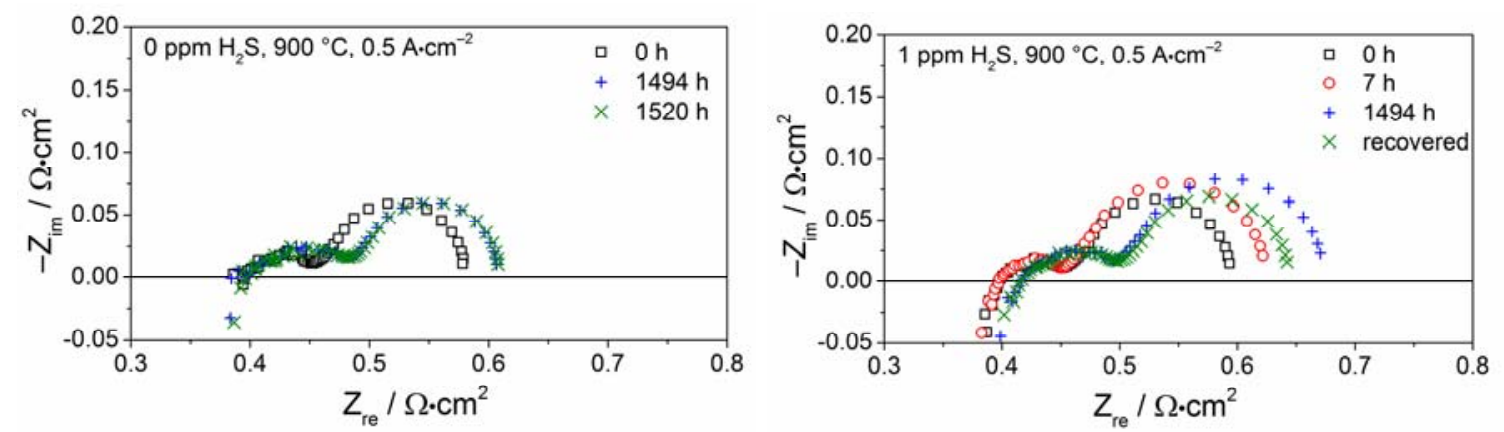

Figure 2. Nyquist plots of impedance spectra of the SOFC recorded at temperature $T=$ $900{ }^{\circ} \mathrm{C}$, and $i=0.5 \mathrm{~A} \cdot \mathrm{cm}^{-2}, p \mathrm{H}_{2}=1.0 \mathrm{~atm}$, and $\mathrm{pO}_{2}=0.21 \mathrm{~atm}$, with different $\mathrm{H}_{2} \mathrm{~S}$ concentrations of (a) $0 \mathrm{ppm}$ and (b) $1 \mathrm{ppm}$. Impedance spectra are shown at times $t=0 \mathrm{~h}$ (black squares), $7 \mathrm{~h}$ (red circles), $1494 \mathrm{~h}$ (blue plus sign) and $1520 \mathrm{~h} / \mathrm{after}$ recovery (green cross).

On the whole, the demonstrated long-term stability of Ni/CGO anodes at $1 \mathrm{ppm}_{2} \mathrm{~S}$ is very promising. However, the employed reaction conditions are not very harsh. Therefore, the investigation of $\mathrm{Ni} / \mathrm{CGO}$ stability at a higher $\mathrm{H}_{2} \mathrm{~S}$ concentration and a lower hydrogen partial pressure is shown in the following. In the transient voltage curves in Figure 3, a Ni/CGObased cell was exposed to $10 \mathrm{ppm}_{2} \mathrm{~S}$ in $\mathrm{pH}_{2}=0.25 \mathrm{~atm}$. Clearly, the sulfur-exposed shows significant voltage degradation within the $90 \mathrm{~h}$ of poisoning.

The impedance spectra in Figure 4 show an increased response at $\sim 1 \mathrm{~Hz}$. This behavior is probably related to a degradation of the anode charge transfer process and was not observed for the sulfur-free sample. No increase of the ohmic resistance was witnessed. As it was shown before, sulfur coverage on $\mathrm{Ni}$ depends on the $\mathrm{pH}_{2} \mathrm{~S} / \mathrm{pH}$ ratio (23). Thus, this could also affect the extent of long-term degradation. In order to further analyze this degradation process, SEM pictures were recorded and are depicted in Figure 5.

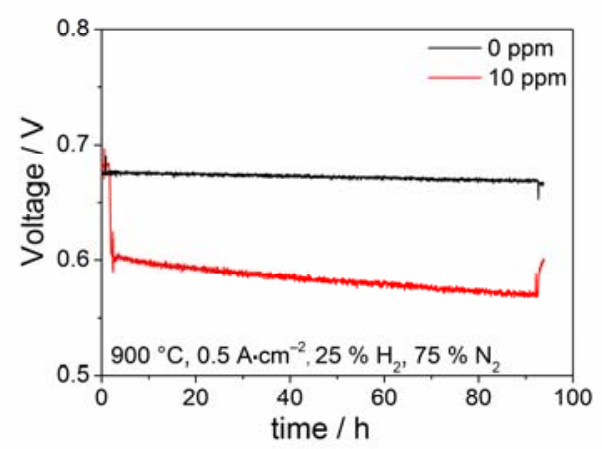

Figure 3. Cell voltage curves as a function of time at $T=900{ }^{\circ} \mathrm{C}$ and $p \mathrm{O}_{2}=0.21 \mathrm{~atm}$. The cells are operated at $i=0.5 \mathrm{~A} \cdot \mathrm{cm}^{-2}, p \mathrm{H}_{2}=0.25 \mathrm{~atm}, p N_{2}=0.75 \mathrm{~atm}$, and with $\mathrm{H}_{2} \mathrm{~S}$ concentrations of 0 and $10 \mathrm{ppm}$. 

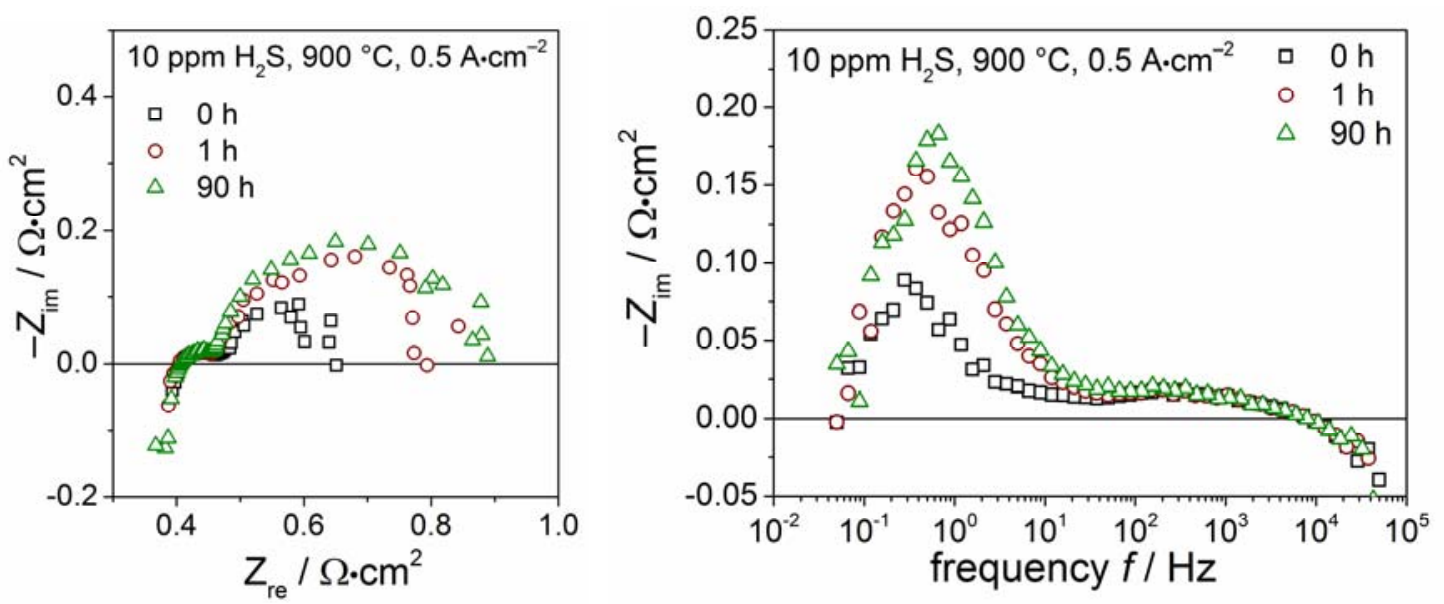

Figure 4. Nyquist and imaginary plot of impedance spectra of the SOFC recorded at temperature $T=900{ }^{\circ} \mathrm{C}$, and $i=0.5 \mathrm{~A} \cdot \mathrm{cm}^{-2}, p \mathrm{H}_{2}=0.25 \mathrm{~atm}, p \mathrm{~N}_{2}=0.75 \mathrm{~atm}$ and $p \mathrm{O}_{2}=0.21$ atm, with a $\mathrm{H}_{2} \mathrm{~S}$ concentrations of $10 \mathrm{ppm}$. Impedance spectra are shown at times $t=0 \mathrm{~h}$ (black squares), $1 \mathrm{~h}$ (brown circles), and $90 \mathrm{~h}$ (green up-pointing triangle).

The SEM picture of the sulfur-exposed sample shows Ni depletion at the interface between $\mathrm{CGO}$ adhesion layer and the $\mathrm{Ni} / \mathrm{CGO}$ functional layer. This behavior is similar to the one observed for Ni/YSZ anodes (3). For Ni/YSZ the degradation was related to the combination of sulfur exposure and high cell overpotential. In the present study, this could also be the case. Other possibilities would be the high $\mathrm{H}_{2} \mathrm{~S}$ concentrations, the large anode overpotential, the high $p \mathrm{H}_{2} \mathrm{~S} / \mathrm{pH}_{2}$, or the increased fuel utilization. In order to shed light onto the real reason, further experiments have to be carried out in the future.
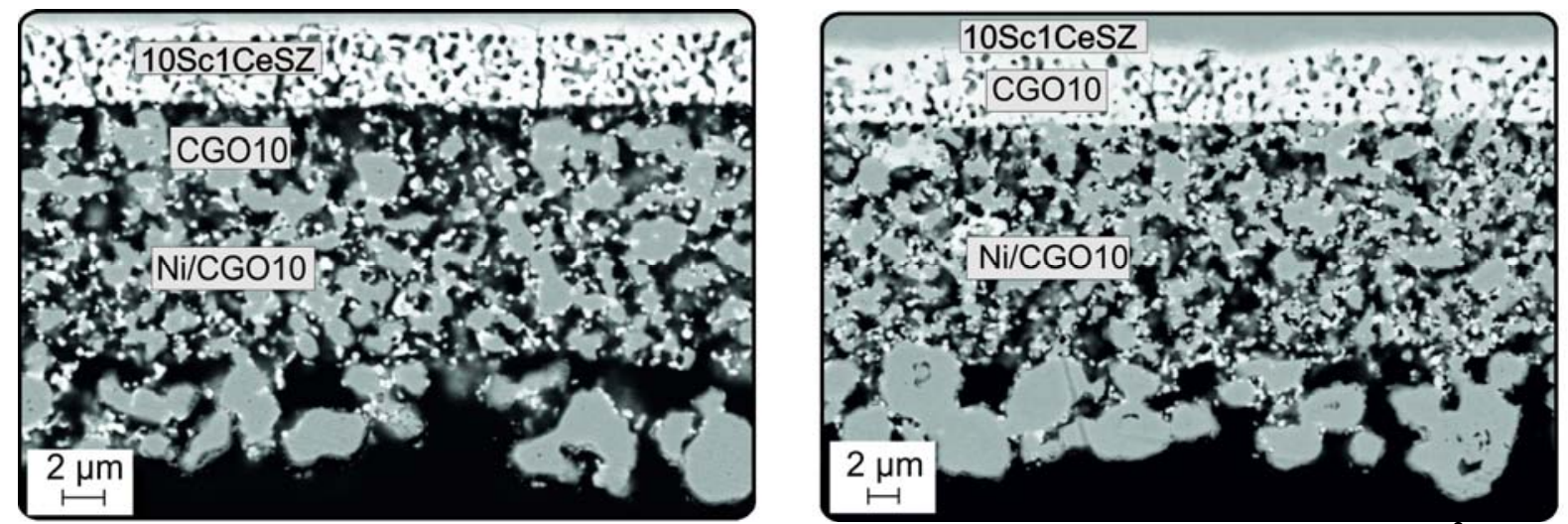

Figure 5: SEM pictures of the Ni/CGO anodes of cells tested at $\mathrm{T}=900{ }^{\circ} \mathrm{C}, 0.5 \mathrm{~A} \cdot \mathrm{cm}^{-2}, p \mathrm{H}_{2}=$ $0.25 \mathrm{~atm}, p \mathrm{~N}_{2}=0.75 \mathrm{~atm}$ with $\mathrm{H}_{2} \mathrm{~S}$ concentrations of (a) $10 \mathrm{ppm}$ and (b) $0 \mathrm{ppm}$.

\section{Summary and Conclusions}

This study has presented a comprehensive analysis of long-term degradation due to sulfur poisoning of $\mathrm{Ni} / \mathrm{CGO} 10$-based ESC. A parameter study of the sulfur-induced long-term degradation behavior of commercial, high-performance single cells was carried out at $900{ }^{\circ} \mathrm{C}$ with varying $\mathrm{H}_{2} / \mathrm{H}_{2} \mathrm{O} / \mathrm{N}_{2} / \mathrm{H}_{2} \mathrm{~S}$ fuel gas atmospheres. The sulfur poisoning periods of the different cells changed from 90 up to $1500 \mathrm{~h}$. It could be shown that Ni/CGO electrodes can be exposed to $1 \mathrm{ppm} \mathrm{H}_{2} \mathrm{~S}$ in pure hydrogen and still be operated without considerable irreversible degradation at a current density of $0.5 \mathrm{~A} \cdot \mathrm{cm}^{-2}$ for $1500 \mathrm{~h}$, demonstrating their promising long-term stability. However, for reduced hydrogen partial pressures in the fuel gas 
and $\mathrm{H}_{2} \mathrm{~S}$ concentration of $10 \mathrm{ppm}$ a significant voltage decrease was observed. Two different sulfur-related degradation processes have been identified. First, a small increase of the ohmic resistance after $1500 \mathrm{~h}$ and second, a degradation of the anode charge transfer process, which is triggered by particularly harsh operating conditions with regards to hydrogen sulfide and hydrogen concentration in the gas phase. The degradation of the Ni/CGO charge transfer process was correlated to a loss of $\mathrm{Ni}$ percolation at the electrolyte/electrode interface. The existence of a stable operating regime for $\mathrm{Ni} / \mathrm{CGO}$ anodes under sulfur exposure could be shown, which encourages further development and optimization of Ni/CGO electrodes.

\section{Acknowledgments}

We gratefully acknowledge financial support by the German Ministry of Education and Research within the framework of the project "SOFC-Degradation: Analyse der Ursachen und Entwicklung von Gegenmaßnahmen" via grant number 03SF0494C. The authors are deeply grateful to Michael Hoerlein for help regarding test bench setup, cell testing and numerous scientific discussions.

\section{References}

1. M. Riegraf, G. Schiller, R. Costa, K. Andreas Friedrich, A. Latz, and V. Yurkiv, J. Electrochem. Soc., 162, F65 (2015).

2. Y. Matsuzaki and I. Yasuda, Solid State Ionics, 132, 261 (2000).

3. A. Hauch, A. Hagen, J. Hjelm, and T. Ramos, J. Electrochem. Soc., 161, F734 (2014).

4. A. Hagen, G. B. Johnson, and P. Hjalmarsson, J. Power Sources, 272, 776 (2014).

5. A. Weber, S. Dierickx, A. Kromp, and E. Ivers-Tiffée, Fuel Cells, 13, 487 (2013).

6. M. Riegraf, V. Yurkiv, G. Schiller, R. Costa, A. Latz, and K. A. Friedrich, J. Electrochem. Soc., 162, 1324 (2015).

7. S. Kavurucu Schubert, M. Kusnezoff, A. Michaelis, and S. I. Bredikhin, J. Power Sources, 217, 364 (2012).

8. C. Xu, P. Gansor, J. W. Zondlo, K. Sabolsky, and E. M. Sabolsky, J. Electrochem. Soc., 158, B1405 (2011).

9. L. Zhang, S. P. Jiang, H. Q. He, X. Chen, J. Ma, and X. C. Song, Int. J. Hydrogen Energy, 35, 12359 (2010).

10. P. Lohsoontorn, D. J. L. Brett, and N. P. Brandon, J. Power Sources, 183, 232 (2008).

11. M. Riegraf, V. Yurkiv, R. Costa, G. Schiller, and K. A. Friedrich, ChemSusChem, 10, 587 (2017).

12. C. Zhang et al., Nat. Mater., 9, 944 (2010).

13. W. C. Chueh, Y. Hao, W. Jung, and S. M. Haile, Nat. Mater., 11, 155 (2011).

14. W. C. Chueh and S. M. Haile, Phys. Chem. Chem. Phys., 11, 8144 (2009).

15. Z. A. Feng, F. El Gabaly, X. Ye, Z.-X. Shen, and W. C. Chueh, Nat. Commun., 5, 1 (2014).

16. S. C. Decaluwe et al., J. Phys. Chem. C, 114, 19853 (2010).

17. T. Nakamura, T. Kobayashi, K. Yashiro, A. Kaimai, T. Otake, K. Sato, J. Mizusaki, and T. Kawada, J. Electrochem. Soc., 155, B563 (2008).

18. B. Iwanschitz, J. Sfeir, A. Mai, and M. Schütze, J. Electrochem. Soc., 157, B269 (2010).

19. V. Papaefthimiou et al., Adv. Energy Mater., 3, 762 (2013).

20. M. P. Hoerlein, G. Schiller, F. Tietz, and K. A. Friedrich, ECS Trans., 68(1), 3553 (2015).

21. M. Gerstl, A. Nenning, R. Iskandar, V. Rojek-Wöckner, M. Bram, H. Hutter, and A. Opitz, Materials, 9, 649 (2016). 
22. D. R. Mullins and T. S. McDonald, Surf. Sci., 601, 4931 (2007).

23. I. Alstrup, J. Rostrup-Nielsen, and S. Røen, Appl. Catal., 1, 303 (1981). 